\section{5 一酸化炭素中毒による聴覚障害}

○收島 和見（九大）

\section{6 高音難聴（主しして加合による）とそ の側頭骨病理組織学的所見}

\author{
○村上㗺孝（日 大） \\ HAROLD F. SCHUKNECHT \\ Mass. Eye \& Ear Infirmary, \\ Harvard Medical School)
}

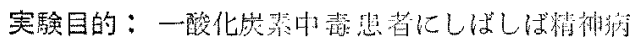

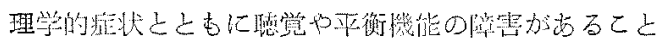

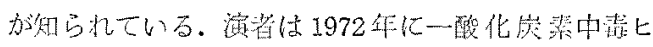

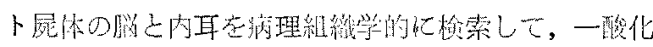

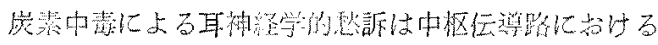

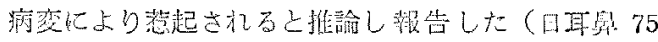

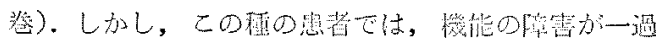
性でるつたり，また怔永続性ておつたりなど空例に上 りさまざきですり，安の府態の理触は未だ允分てな い.

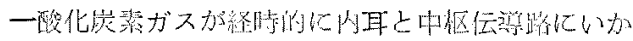

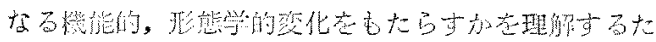
以江次の唾物实䟻在行つた。

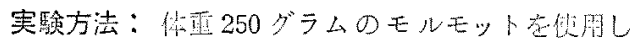

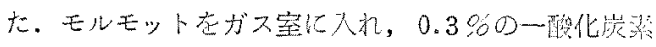

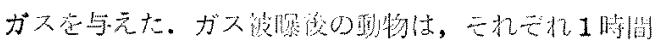

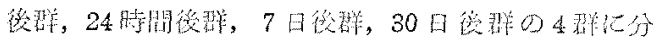

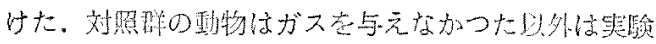
踓上同じう法で取报つた。

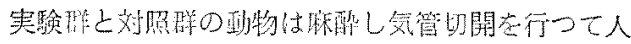

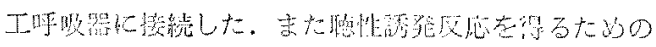

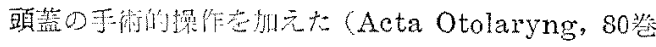

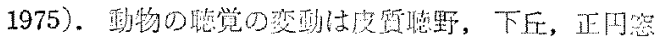

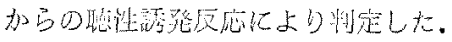

実駼成績：1時阔後群では皮質上下丘加らの反应

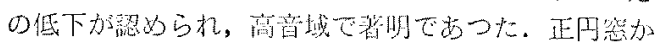

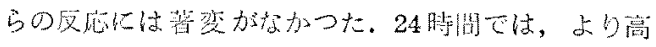

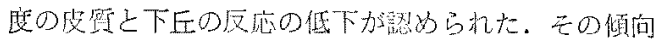

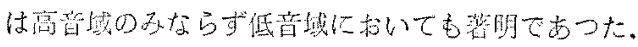

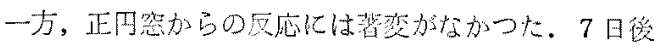

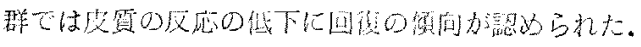

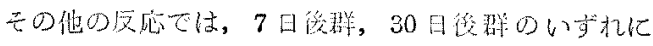
古著变加加つた。

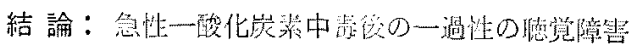
は主として㥁觉中枢路に怙けるリバーシブルな神経病 理学的ならびに神経化学的变化によるもの上考元た。

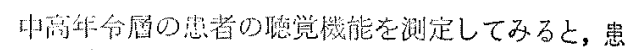

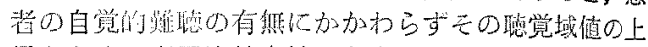

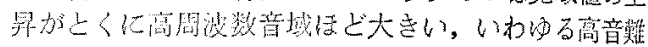

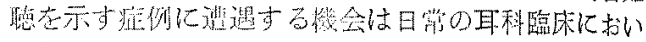
ても碓なことではない，わ加れは今回，ての上うな

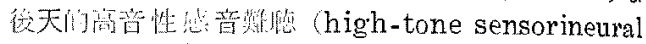

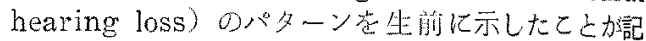

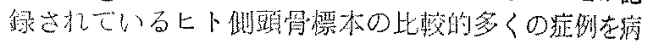

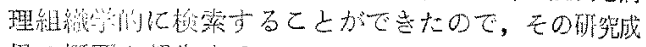
果の概要在班些する。

研究枌料・方法：研究材棹に注 Massachusets Eye \& Ear Infirmary に怙ける Otopathology

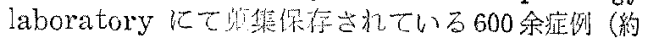

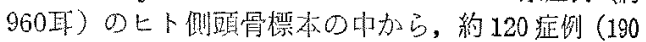

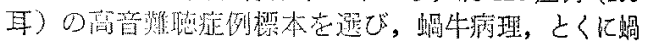

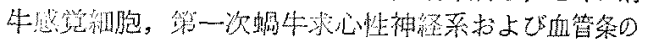

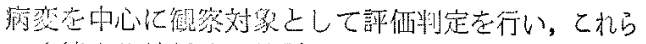

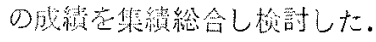

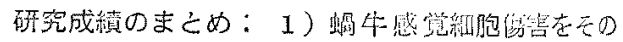

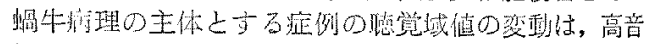

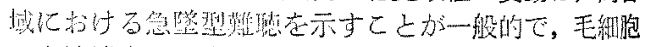

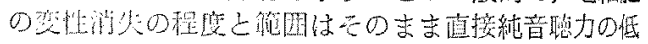

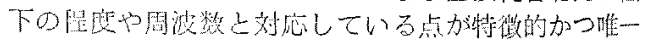

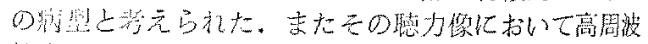

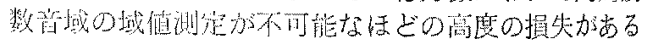

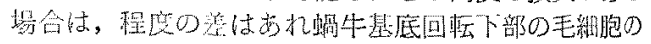

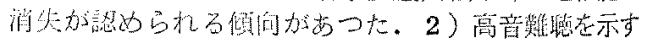

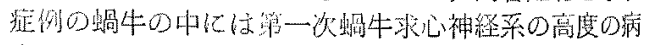

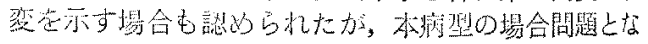

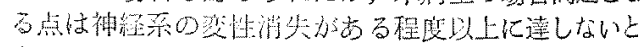

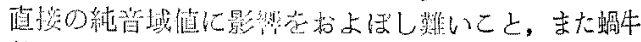

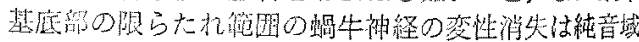

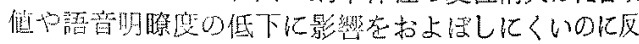

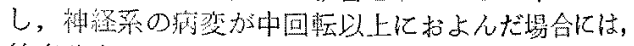

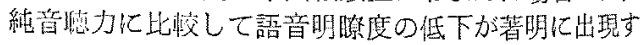

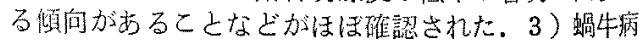
理上ほ上んど認むべき翌化がないか，きわめて怪い病 変しかないのに作音域加ら菖音域化加て直線的に下 降してゆく型の省力像走示す症例群が存在する，本病

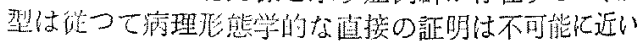
が，结牛の運動力学 (motion mechanies) 的障暂

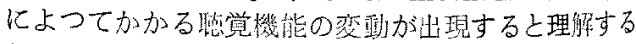
ならば，各症例を諭理的に説明が可能之思わ机た。上 記病型は售型䉓独で出現する場合むあり，また相加的 混合满型を示す症例屯あつた。 